\title{
Influence of Whey Proteins Addition on Mechanical Stability of Biopolymer Beads with Immobilized Probiotics
}

\author{
NATAŠA S. OBRADOVIĆ, University of Belgrade, \\ Innovation Centre of the Faculty of \\ Technology and Metallurgy, Belgrade \\ TANJA Ž. KRUNIĆ, University of Belgrade, \\ Innovation Centre of the Faculty of \\ Technology and Metallurgy, Belgrade \\ IVANA D. DAMNJANOVIĆ, University of Belgrade, \\ Innovation Centre of the Faculty of \\ Technology and Metallurgy, Belgrade \\ MAJA S. VUKAŠINOVIĆ-SEKULIĆ, University of Belgrade, \\ Faculty of Technology and Metallurgy, Belgrade \\ MARICA B. RAKIN, University of Belgrade, \\ Faculty of Technology and Metallurgy, Belgrade \\ MARKO P. RAKIN, University of Belgrade, \\ Faculty of Technology and Metallurgy, Belgrade \\ BRANKO M. BUGARSKI, University of Belgrade, \\ Faculty of Technology and Metallurgy, Belgrade
}

Original scientific papaer

UDC: 637.142

\begin{abstract}
Biopolymer carriers are widely used for immobilization of the bioactive compounds and different type of the cells. The aim of this study was to analyze influence of whey proteins addition on mechanical strength of Ca-alginate beads and survival of probiotic bacteria during the whey fermentation process. Mechanical stability of beads was analyzed up to $30 \%$ of bead's deformation using compression method between two flat plates. The fermentation was carried out with probiotic starter culture ABY-6 until $p H=4.6$. The results indicate that the addition of whey proteins in alginate solution increases strength of the beads after fermentation in comparison with alginate beads without proteins and extends the shelf life of products through improving the viability of probiotics.
\end{abstract}

Key words: biopolymer beads, whey proteins, mechanical stability, probiotics

\section{INTRODUCTION}

Natural biopolymers are often used as carriers mainly due to their high availability, biocompatibility and biodegradability [1-3]. Biopolymer beads made from interactions between proteins and polysaccharides have found application in several industrial fields such as food, agricultural, pharmaceutical and biomedical [4, 5]. Among biodegradable polymers, alginates are one of the most widely used for immobilization and contro-

Author's address: Nataša Obradović, University of Belgrade, Innovation Centre of the Faculty of Technology and Metallurgy, Belgrade, Karnegijeva 4

Paper received: 13.03.2015

Paper accepted: 09.04.2015. lled release due to their ability to form gels under acceptable conditions thus allowing retained biological activity of the encapsulated material [6-8]. Alginate, whey proteins or combinations including whey protein or alginate have been studied for use as delivery systems [9-11]. Some authors have reported that alginates can form strong complexes with other natural polyelectrolytes such as pectin forming hydrogels upon addition of divalent cations (e.g., Ca2+) improving the mechanical and chemical stability of the alginate beads [12-14]. Recently, it was shown that alginate $\mathrm{M} / \mathrm{G}$ ratio, total biopolymer concentration, cation type and concentrations have a great influence on the textural properties of the beads [13-16]. Alginate beads prepared from sodium alginate of high guluronic acid 
content were found to have greater stiffness since most of the divalent cations bind to the guluronic sequences but only to an extent or not at all to the mannuronic acid and alternating blocks. Increasing the concentration of alginate and gelling ions also generated a similar effect [15].

The mechanical stability of the microcapsules is important factor for growth and viability of encapsulated cells. Beads should be strong enough to withstand the shear forces and changes in the microenvironment condition during application and storage.

Therefore, the objective of the present study was to examine the mechanical properties of calcium alginate beads made with addition of whey proteins and probiotic cell survival during the fermentation process.

\section{MATERIALS AND METHODS}

\subsection{Preparation of alginate beads with whey proteins and probiotic cells}

Alginate beads with probiotic cells were produced using an extrusion technique. A freeze-dried dairy starter culture 'Lactoferm ABY-6' (Streptococcus salivarius ssp. thermophilus, Lactobacillus delbrueckii ssp. bulgaricus, Lactobacillus acidophilus and Bifidobacterium bifidum) supplied by Biochem S.R.L. (Monterotondo, Roma, Italy) was mixed with sodium alginate solution in ratio $1: 1.5(\mathrm{v} / \mathrm{v})$.

Alginate-cell suspension containing $1.6 \%(\mathrm{w} / \mathrm{v})$ sodium alginate was extruded by syringe pump (Racel, Scientific Instruments, Stamford, CT, USA) into 2\% $(\mathrm{w} / \mathrm{v})$ calcium chloride as presented in Figure 1. Calcium chloride $\mathrm{CaCl}_{2}$ dihydrate (Acros Organics, USA) was used as the gelling cation.

Alginate beads were obtained by keeping distance of $3 \mathrm{~cm}$ between the blunt needle tip (18-gauge) and gelling solution. The same technique was used for preparation of alginate beads with whey proteins.

Cell-whey suspension was mixed with $15 \%(\mathrm{w} / \mathrm{v})$ whey protein solution (DMV International, Netherlands) and then mixed with $1.6 \%(\mathrm{w} / \mathrm{v})$ sodium alginate solution. After extrusion, the beads were allowed to harden for $30 \mathrm{~min}$. The beads were separated by filtration, transferred to a sterile Petri dish and stored at $4^{\circ} \mathrm{C}$ in $0.2 \%(\mathrm{w} / \mathrm{v})$ yeast extract solution [17].

The shape and diameter of the beads were examined after immobilization process by using an optical microscope (Carl Zeiss Microscopy GmbH, UK). The average diameter was calculated from measurements of 22 beads.

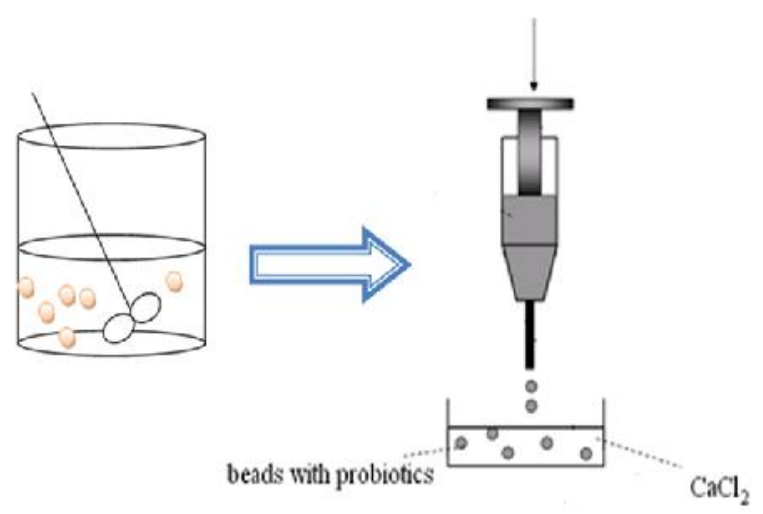

Figure 1 - Preparation of alginate beads with probiotics and whey proteins using extrusion technique

\subsection{Fermentation and enumeration of immobilized probiotic bacteria}

Experiments were performed in $100 \mathrm{ml}$ Erlenmeyer flasks containing $50 \mathrm{ml}$ fermentation medium (70\% pasteurized whey and $30 \%$ bovine milk). Whey and bovine milk were obtained from domestic dairy plant Imlek d.o.o. (Belgrade, Serbia). The chemical composition of whey was: total solids $9.8 \pm 0.03 \%$ $(\mathrm{w} / \mathrm{v})$; protein $2.6 \pm 0.012 \%(\mathrm{w} / \mathrm{v})$; fat $1.05 \pm 0.08 \%$ $(\mathrm{w} / \mathrm{v})$ and lactose $5.6 \pm 0.114 \%(\mathrm{w} / \mathrm{v})$. Fermentation was carried out at $42{ }^{\circ} \mathrm{C}$ until $\mathrm{pH}$ value of 4.6 was attained and stopped by quick cooling. Whey, bovine milk and whey protein solution were pasteurized at $60^{\circ} \mathrm{C}$ for $60 \mathrm{~min}$, and cooled at room temperature.

For quantitative measurements of cell viability, 1 gram of the beads was dissolved in $9 \mathrm{ml}$ sodium citrate $(2.0 \%, \mathrm{w} / \mathrm{v})$. Cell number of $S$. thermophilus was determined by pour plate counting method on M17 agar unlike the number of viable cell of L. bulgaricus, L. acidophilus and B. bifidum which was determined by pour plate counting method on MRS according to already published study [18].

\subsection{Compression testing of the beads}

Compression testing of alginate beads were performed using Universal Testing Machine, AG-Xplus (Shimadzu, Japan) equipped with a $100 \mathrm{~N}$ force load cell (force range from 0.01 to $100 \mathrm{~N}$ ). The compression was performed up to a $30 \%$ of sample deformation at compression speeds $1 \mathrm{~mm} / \mathrm{min}$ according to method described in our previous work [19]. Thirty beads from each sample were submerged in distilled water in Petri dish and compressed between two flat plates. Automatic detection of the contact between plate and single bead was carried out with a contact force of $0.1 \mathrm{~N}$ under identical test conditions. The equipment is consisted of a mobile plate moving vertically at a constant speed which was set to return to the original position immediately after compression. The mechanical strength of the beads was measured by 
compressing the individual bead and software TRAPEZIUMX (version 1.13) was used for recording and analyzing the experimental data. The values of maximal forces were determined using the force-displacement curves obtained after the compression. The experiments were performed in triplicate. All the values are expressed as mean \pm standard deviation. Mean values were analyzed using Microsoft Office Excel 2007 software (Microsoft Corporation, WA, USA).

\section{RESULTS AND DISCUSSION}

The results indicate that the shape of the beads did not change significantly with addition of whey proteins. The mean diameter of formed $\mathrm{Ca}$-alginate beads was $2.95 \pm 0.039 \mathrm{~mm}$.

\subsection{Influence of protein addition on viability of probiotic cells}

Initial number of viable cells was $7.65 \pm 0.11$ ( $\log$ $\left.\mathrm{CFU} \mathrm{g}^{-1}\right)$ for alginate beads and $8.08 \pm 0.06\left(\log \mathrm{CFU} \mathrm{g}^{-}\right.$ $\left.{ }^{1}\right)$ for alginate beads with whey proteins. During the fermentation, number of viable cells in beads without proteins increases for $0.39\left(\log \mathrm{CFU} \mathrm{g}^{-1}\right)$ while in beads with proteins increases for $0.86\left(\log \mathrm{CFU} \mathrm{g^{-1 }}\right)$, and reaches values $8.04 \pm 0.13\left(\log \mathrm{CFU} \mathrm{g}^{-1}\right)$ and $8.92 \pm 0.29$ $\left(\log \mathrm{CFU} \mathrm{g} \mathrm{g}^{-1}\right)$, respectively (Figure 2$)$. Based on the results it could be concluded that presence of whey proteins improves cell growth during the fermentation.

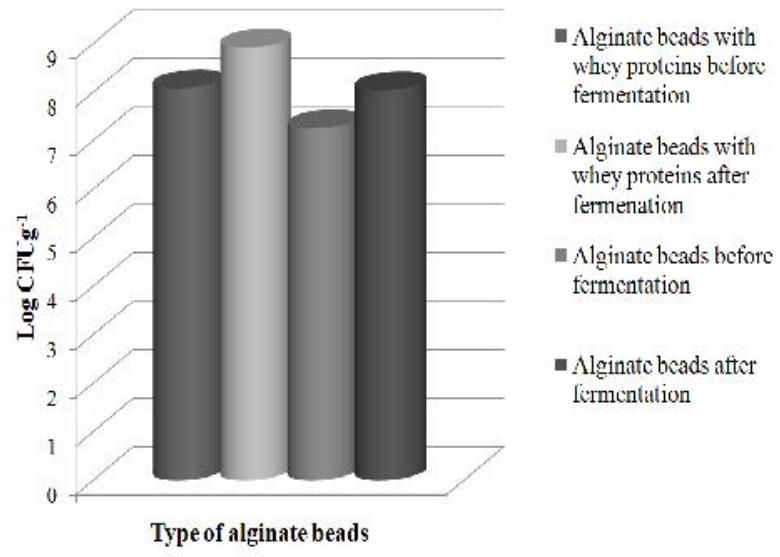

Figure 2 - Cell viability of probiotics in alginate beads with and without whey proteins

These findings are in agreement with the results obtained for microparticles also made from whey protein in combination with alginate which have shown as good carriers for protection of probiotic yeast and bacteriophage Felix O1 [20,21].

\subsection{Mechanical stability of alginate beads}

In many applications, the hydrogel beads are subjected to mechanical forces because of that it is necessary to determine their mechanical properties. During the compression experiments, the beads were imposed by the strain and measured corresponding force. From the obtained force-displacement curves presented in Figure 3, it can be noticed that presence of whey proteins increase maximal force values for tested percentage of deformation. Based on this observation it could be said that the whey proteins have additional effect on stability of the carrier. This effect could be explained by the ability of whey proteins to form gel with $\mathrm{Ca}^{2+}$ ions from fermentation medium. The presence of $\mathrm{Ca}^{2+}$ ions induced whey protein gelation similar to alginate hydrogels $[7,9]$.

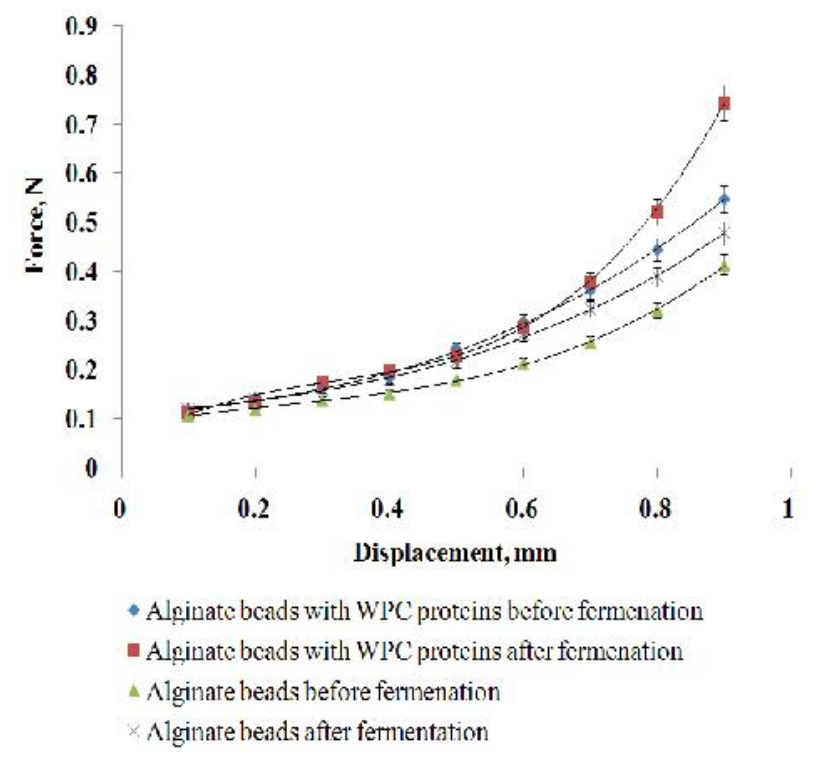

Figure 3 - Comparison of force-displacement polynomial fitted curves of alginate beads before and after fermentation process (30\% deformation, compression speed $1 \mathrm{~mm} / \mathrm{min}$, means values \pm $S D, n=30$ )

Comparing obtained force results before and after fermentation it can be also concluded that fermentation process increased strength of the alginate beads with and without whey proteins. Whey based fermentation medium is shown good potential to be used in combination with alginate beads because of its positive effect on mechanical stability of the beads and growth of probiotics.

\section{CONCLUSION}

The present study has shown that addition of whey proteins has significant influence on mechanical stability of calcium alginate beads. According to obtained results it can be concluded that presence of proteins improves mechanical strength of the beads. The results also indicate that fermentation process increases the maximal force of alginate beads for tested deformation percentage. The analysis of cell viability before and after fermentation has shown increase of growth of probiotics which points that this type of carrier can be 
suitable for production of fermented whey based beverages.

\section{ACKNOWLEDGEMENTS}

The authors gratefully acknowledge the support from the Ministry of Education, Science and Technological Development of the Republic of Serbia through the projects III 46010 and ON 174004.

\section{REMARK}

This paper was presented at $13^{\text {th }}$ Young Researchers Conference Materials Science and Engineering, Belgrade, December 10-12, 2014.

\section{REFERENCES}

[1] Chen H., Yuan L., Song W., Wu Z., Li D., Prog. Polym. Sci, 33, p. 1059-1087, 2008.

[2] Fioramonti S. A., Perez A. A., Aríngoli E. E., Rubiolo A. C., Santiago L. G., Food Hydrocolloid., 35, p.129-136, 2014.

[3] Li W., Wu G., Chen H., Wang M., Colloid. Surface A, 333, p. 133-137, 2009.

[4] Chen L., Subirade M., Biomaterials, 27, p. 46464654, 2006.

[5] Belščak-Cvitanović, A., Stojanović, R., Manojlović, V., Komes, D., Juranović Cindrić, I., Nedović, V., Bugarski, B., Food Res. Int., 44, p. 1094-1101, 2011.

[6] Wichchukit S., Oztop M.H., McCarthy M.J., McCarthy K.L., Food Hydrocolloid., 33, p. 66-73, 2013.

[7] Messaoud G.B., Sánchez-González L., Jacquot A., Probst L. Desobry, S., J. Colloid. Interf. Sci., 440, p. $1-8,2015$.

[8] Bokkhim H., Bansal N., Grøndahl L., Bhandari B., Food Hydrocolloid., p. 1-7, 2014.
[9] Chen L. Y., Subirade M., Biomaterials, 27(26), p. 4646-4654, 2006.

[10]Chen L. Y., Subirade M., Eur. J. Pharm. Biopharm., 65(3), p. 354-362, 2007.

[11]Subirade M., Hebrard G., Hoffart V., Beyssac E., Cardot J. M., Alric M., J. Microencapsul., 27(4), p. 292-302, 2010.

[12]Fang Y., Al-Assaf S. Phillips G.O., Nishinary K., Funami T., Williams P. A., Carbohydrate Polymers, 72, p. 334-341, 2008.

[13]Sandoval-Castilla O., Lobato-Calleros C., GarcíaGalindo H.S., Alvarez-Ramírez J., Vernon-Carter E. J., Food Res. Int., 43, p. 111-117, 2010.

[14]Bhujbal S.V., Paredes-Juarez G.A., Niclou S.P., Vos P., J. Mech. Behav. Biomed., 37, p. 196-208, 2014.

[15]Chana E. S., Limb T., Voob W., Pogakub R., Ti Teyc B., Zhangd Z., Particuology, 9, p. 228-234, 2011.

[16]Mørch Y. A., Biomacromolecules, 7(5), p. 14711480, 2006.

[17]Gündüz, M., Lactic acid production by lactobacillus casei nrrl b-441 immobilized in chitosan stabilized Ca-alginate beads, Master Thesis, Izmir Institute of Technology, Turkey, p. 28-29, 2005.

[18]Vrbaški Lj. Markov S., Praktikum iz mikrobiologije. Prometej, Novi Sad, p. 102-105, 1993 (in Serbian).

[19]Tomović N. S., Trifković K. T., Rakin M. P., Rakin M. B., B. Bugarski M., Chem. Ind. Chem.Eng.Q., DOI:10.2298/CICEQ140228043T.

[20]Hébrard G., Hoffart V., Beyssac E., Cardot J.M., Alric M., Subirade M., J. Microencapsul., 27, p. 292$302,2010$.

[21]Tang Z., Huang X.,. Baxi S, Chambers J. R., Sabour P. M., Wang Q., Food Res. Int., 52, p. 460-466, 2013.

\section{REZIME}

\section{UTICAJ DODATKA PROTEINA SURUTKE NA MEHANIČKU STABILNOST BIOPOLIMERNIH NOSAČA SA IMOBILISANIM PROBIOTICIMA}

Biopolimerni nosači su najčešće korišćenih nosači za imobilizaciju bioaktivnih jedinjenja i različite vrste ćelija. Cilj ovog istraživanja je bila analiza uticaja dodatka proteina surutke na mehaničku čvrstoću kalcijum alginatnih čestica i preživljavanje probiotskih bakterija tokom procesa fermentacije surutke. Mehanička stabilnost nosača je analizirana do $30 \%$ deformacije čestica metodom kompresije između dve ravne ploče. Fermentacija se odvijala pomoću probiotiske starter kulture ABY-6 do vrednosti $\mathrm{pH}=$ 4.6. Rezultati ukazuju da dodatak proteina surutke u alginatni rastvor povećava čvsrtoću čestica nakon fermentacije u poređenju sa alginatnim česticama bez proteina i produžava rok trajanja proizvoda kroz unapređenje preživljavanja probiotskih bakterija .

Ključne reči: biopolimerni nosači, protein surutke, mehanička stabilnost, probiotici 